

\section{SELECTED WEIGHTS AND MEASURES PUBLICATIONS OF THE NATIONAL BUREAU OF STANDARDS}

NBS HANDBOOK 44

1965 (Replacement Sheets

issued annually)

NBS HANDBOOK 67

NBS HANDBOOK 82

NBS HANDBOOK 94

NBS HANDBOOK 98

NBS HANDBOOK 99

NBS CIRCULAR 593

NBS MISCELLANEOUS PUBLICATION 247

NBS MISCELLANEOUS PUBLICATION 286

NBS TECHNICAL NOTE 196
Specifications, Tolerances, and Other Technical Requirements for Commercial Weighing and Measuring Devices, Looseleaf (binder not included) $\$ 2.00$

Checking Prepackaged Commodities

Weights and Measures Administration

Examination of Weighing Equipment

Examination of Farm Milk Tanks

Examination of Liquefied Petroleum Gas LiquidMeasuring Devices

Federal Basis for Weights and Measures

Weights and Measures Standards for the United States-a brief history

Units of Weights and Measures-Definitions and Tables of Equivalents

Report of the Investigation of Slow-Flow Meters for Fuel Oil Distribution Systems
1.75

3.00

.35

.35

.45

.40

2.25

.20

\section{REPORTS OF THE NATIONAL CONFERENCE}

ON WEIGHTS AND MEASURES

1966

1967

1968

1969
MISCELLANEOUS PUBLICATION 290

SPECIAL PUBLICATION 297

SPECIAL PUBLICATION 311

SPECIAL PUBLICATION 318
1.00

1.25

1.25

1.50

ORDER ALL PUBLICATIONS, WITH REMITTANCE, FROM THE SUPERINTENDENT OF DOCUMENTS, U.S. GOVERNMENT PRINTING OFFICE, WASHINGTON, D.C. 20402 


\title{
Specifications and Tolerances for Reference Standards and Field Standard Weights and Measures
}

\section{Specifications and Tolerances for Field Standard Measuring Flasks}

\author{
Blayne C. Keysar \\ Office of Weights and Mcasures \\ Institute for Applied Technology \\ National Bureau of Standards \\ Washington, D.C. 20234
}

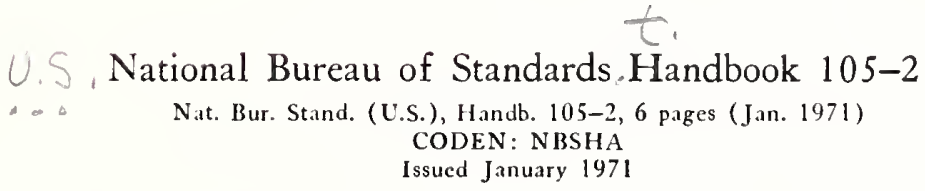

For sale by the Superintendent of Documents, U.S. Government Printing Office, Washington, D.C. (Order by SD Catalog No. C $13.11: 105-2)$. Price 25 Cents 
FEB \& 41971 $n_{0}+\Delta, C,-R$

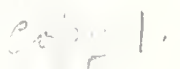

Library of Congress Catalog Card Number: 68-26245 


\section{Contents}

Introduction

Specifications: U. S. Customary

1. Sizes

2. Material

3. Workmanship

4. Design

5. Graduation lines

6. Scales

7. Inscriptions

8. Temperature

9. Tolerances

Specifications: Metric

1. Sizes

2. Material, Workmanship, Design, Graduation lines, Inscriptions

3. Scales

4. Temperature

5. Tolerances

Tables

Table 1

Table 2

Table 3

Table 4

Illustrations

Figure 1

Figure 2

Figure 3

Figure 4

Definitions

Abbreviations

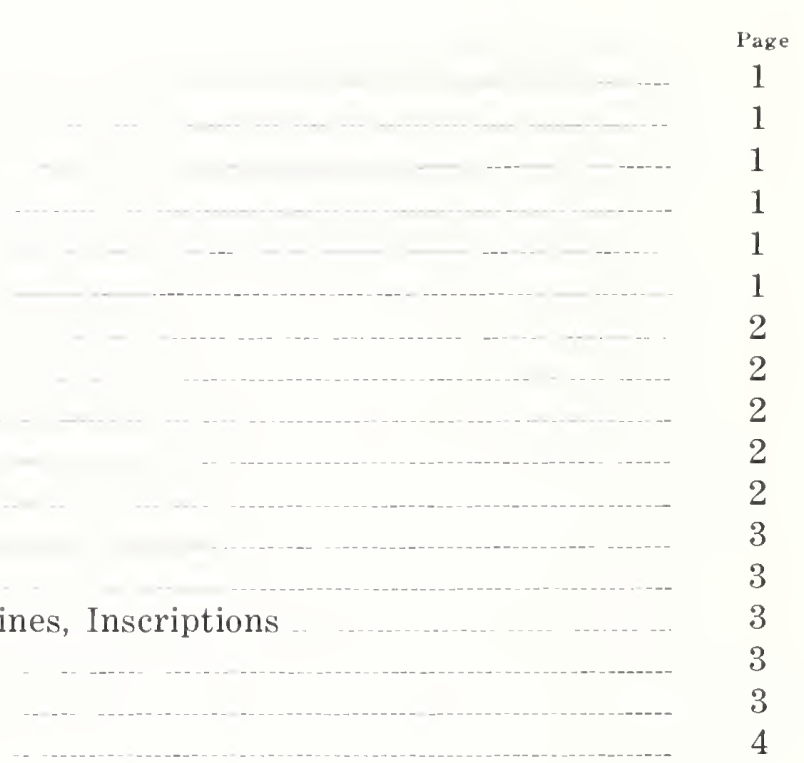


-

- 


\title{
Specifications and Tolerances for Reference Standard and Field Standard Weights and Measures
}

\author{
2. Specifications and Tolerances \\ for Field Standard Measuring Flasks
}

\author{
Blayne C. Keysar
}

\begin{abstract}
These specifications and tolerances are recommended as minimum requirements for standards used in the field by State and local weights and measures officials in quantity determinations of liquid commodities.
\end{abstract}

Key Words: Accurate measurements of volume of liquids; field standard measuring flasks; specifications; tolerances; weights and measures inspection.

\section{Introduction}

Field standard measuring flasks are intended to be used by weights and measures officials, ${ }^{1}$ manufacturers and distributors of liquid products, research and testing laboratories personnel, and others concerned with accurate measurements of volumes of liquids.

The materials, design, fabrication, and error limitation of the field standards herein specified are intended to permit their use in normal testing operations as standards having nominal values. Field standards are relatable to the U. S. Prototype standards for length, mass, and capacity, through standards which have been supplied to the State Weights and Measures laboratories by the National Bureau of Standards. Field standards should be calibrated periodically. The frequency of calibration required will depend upon usage of the standards. Comparisons against other standards should be performed occasionally to detect those standards in need of recalibration.

Use of these volumetric standards at all appropriate levels of manufacture, distribution, and weights and measures inspection will help promote accuracy and uniformity in commerce.

\section{Specifications: U.S. Customary}

\section{Sizes}

1.1. A set of U.S. customary field standard

\footnotetext{
1 Procedures for weights and measures inspection of commercial devices are contained in NBS Handbook 44, "Specifications, Tolerances, and Other Technical Requirements for Commercial Weighing and Measuring Devices."
}

flasks consists of a 2-fluid ounce cylindrical graduate and one each 1 gill, $1 / 2$ pint, 1 pint, 1 quart, $1 / 2$ gallon, and 1 gallon graduated neck flasks.

\section{Material}

2.1. A field standard flask shall be made of borosilicate glass.

\section{Workmanship}

3.1. The flask shall be transparent and free from chips, cracks, stones, and other defects that detract from its appearance or that may distort the appearance of the liquid surface under the graduated portion, or impair its serviceability.

\section{Design}

4.1. The design shall conform to the general configuration in the illustrations. The inscriptions and graduation lines shall be placed in the same relationship to each other and to the position on the flask as shown.

4.2. Any cross section taken in a plane perpendicular to the vertical axis shall be circular.

4.3. The shape shall permit complete emptying and thorough cleaning.

4.4. Each shall be equipped with a hexagonal base that is perpendicular to the vertical axis. (The hexagonal base, used for maximum stability, may be omitted from the 1 gallon size since its size and shape eliminates the necessity for a base.) 
4.5. The height of the graduated portion of the cylindrical graduate shall be at least 5 times the inside diameter.

5. Graduation Lines

5.1. Graduation markings shall be sharply defined lines of uniform width not to exceed 0.3 millimeter.

5.2. The lines shall be perpendicular to the vertical axis of the flask.

5.3. The graduation lines, if etched and filled, shall extend completely around the neck. Due to the difficulty in extending stained or enameled lines completely around the neck, a gap of $4 \mathrm{~mm}$ at the closure, or meeting point, is permitted. This gap must be approximately 90 from line of vision when the flask is viewed from the front so as to not interfere with setting a meniscus.

5.4. Subdivision lines shall extend at least halfway around the neck.

5.5. Graduation lines shall be applied by one of the following methods: Etched and filled with a permanent pigment; application of a stain which is fired into the glass without etching; application of an enamel fired onto the glass without etching.

5.6. If a pigment or enamel is used, the nominal volume line (and the 1 fluid ounce line on the cylindrical graduate) shall be of a contrasting color.

5.7. Main graduation lines shall be numbered with the number being placed immediately above the line. (See illustrations.)

\section{Scales}

6.1. The scale on the graduate shall be divided into fluid drams, and labeling shall so indicate (see illustrations) with the appropriate abbreviation: $\mathrm{fl} \mathrm{dr}$. At each 2 fluid drams there shall be a main graduation line. Each subdivision shall be $1 \%$ fluid dram.

6.2. Subdivision lines on the graduate shall be onitted between the base and the first numbered line. (Striation occurs in the glass in this area, being caused during manufacture when the base is joined to the cylindrical portion.)

6.3. Each nominal capacity line and the 1 fluid ounce line on the graduate shall be labeled with the appropriate capacity.

6.4. The scale on the flasks shall be graduated on each side of (above and below) the nominal line on each size as shown in table 1.

\section{Inscriptions}

7.1. Each standard shall be permanently and legibly marked with (1) the manufacturer's name or trademark; (2) serial or identification number; (3) the word "delivers"; (4) capacity ; (5) temperature of calibration; and,
(6) drainage time (10 seconds). On U.S. Customary standard glassware all letters except unit abbreviations are to be upper case. (figs. 1 and 2).
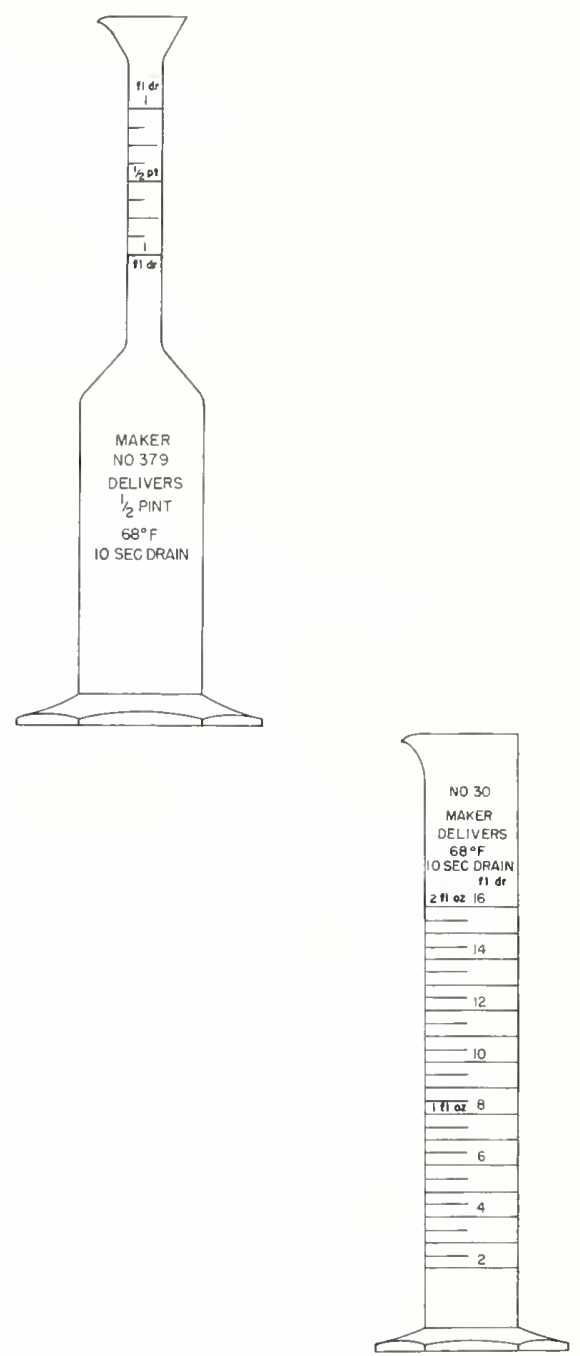

Figure 1. One half pint measuring flask.

FIGURE 2. Two fluid ounce cylindrical graduate.

7.2. The numbers and letters indicating the capacity at the various points shall be placed immediately above the line to which they refer.

\section{Temperature}

8.1. The calibration temperature shall be 68 ${ }^{\circ} \mathrm{F}$.

\section{Tolerances}

9.1. The difference between the actual volumes and indicated volumes at the prescribed temperature $(68 \mathrm{~F})$ shall be not greater than that shown in table 2. 
Table 1. Scale Units for U.S. Customary Flasks

\begin{tabular}{l|c|c}
\hline Size & $\begin{array}{c}\text { Graduation on Each } \\
\text { Side of Nominal }\end{array}$ & $\begin{array}{c}\text { Minimum } \\
\text { Graduation }\end{array}$ \\
\cline { 2 - 3 } Gill & $1 / 2 \mathrm{fl} \mathrm{dr}$ & $1 / 4 \mathrm{fl} \mathrm{dr}$ \\
$1 / 2$ Pint & 1 & $1 / 4$ \\
Pint & 2 & $1 / 2$ \\
Quart & 4 & 1 \\
1/2 Gallon & 6 & 1 \\
Gallon & 8 & 1 \\
\hline
\end{tabular}

Table 2. Tolerances for U.S. Customary Field Standard Flasks and Cylinders (with conversions to milliliters)

\begin{tabular}{|c|c|c|c|c|c|c|}
\hline \multicolumn{3}{|c|}{ Nominal Capacity at $68^{\circ} \mathrm{F}$} & \multicolumn{2}{|c|}{$\begin{array}{c}\text { Tolerances } \\
\text { at Nominal Capacity } \\
\text { Graduations }\end{array}$} & \multicolumn{2}{|c|}{$\begin{array}{l}\text { Tolerances at Total } \\
\text { or Partial Capacity } \\
\text { (Graduated Portion) }\end{array}$} \\
\hline $\begin{array}{l}1 \text { Gill } \\
1 / 2 \text { Pint } \\
1 \text { Pint } \\
1 \text { Quart } \\
1 / 2 \text { Gallon } \\
1 \text { Gallon } \\
2 \text { Fluid Ounce } \\
\text { Cylinder }\end{array}$ & $\begin{array}{r}\text { 1,920 Minims } \\
3,840 \text { Minims } \\
\text { 7,680 Minims } \\
\text { 15,360 Minims } \\
\text { 30,720 Minims } \\
\text { 61,440 Minims } \\
960 \text { Minims }\end{array}$ & $\begin{array}{r}118.3 \mathrm{ml} \\
236.6 \mathrm{ml} \\
473.2 \mathrm{ml} \\
946.3 \mathrm{ml} \\
1892.7 \mathrm{ml} \\
3785.4 \mathrm{ml} \\
59.1 \mathrm{ml}\end{array}$ & $\begin{array}{l} \pm 3 \text { Minims } \\
\pm 4 \text { Minims } \\
\pm 7 \text { Minims } \\
\pm 12 \text { Minims } \\
\pm 16 \text { Minims } \\
\pm 20 \text { Minims } \\
\pm 5 \text { Minims }\end{array}$ & $\begin{array}{l}0.18 \mathrm{ml} \\
0.25 \mathrm{ml} \\
0.43 \mathrm{ml} \\
0.74 \mathrm{ml} \\
0.99 \mathrm{ml} \\
1.23 \mathrm{ml} \\
0.31 \mathrm{ml}\end{array}$ & $\begin{array}{l} \pm 1.0 \text { Minims } \\
\pm 1.5 \text { Minims } \\
\pm 3.0 \text { Minims } \\
\pm 5.0 \text { Minims } \\
\pm 5.0 \text { Minims } \\
\pm 5.0 \text { Minims } \\
\pm 5.0 \text { Minims }\end{array}$ & $\begin{array}{l}0.06 \mathrm{~m} \\
0.09 \mathrm{~m} \\
0.18 \mathrm{~m} \\
0.31 \mathrm{~m}] \\
0.31 \mathrm{~m} \\
0.31 \mathrm{~m} \\
0.31 \mathrm{~m}\end{array}$ \\
\hline
\end{tabular}

\section{Specifications: Metric}

\section{Sizes}

1.1. A set of metric field standard flasks consists of a 50 milliliter cylindrical graduate and one each 100 milliliter, 250 milliliter, 500 milliliter, 1 liter, and 2 liter graduated neck flasks.

\section{Material Workmanship, Design, Graduation Lines, Inscriptions}

2.1. Specifications for material, workmanship, design, graduation lines, and inscriptions shall be the same as those for a U.S. Customary set. (Also, see figs. 3 and 4.)

\section{Scales}

3.1. The scale on a cylindrical graduate shall be divided into milliliters, and labeling shall so indicate (see illustrations) with the appropriate abbreviation: $\mathrm{ml}$. At each 10 milliliters there shall be a main graduation line. Each subdivision shall be 1 milliliter.
3.2. The scale on the flasks shall be graduated on each side of (above and below) the nominal line on each size, as shown in table 3 .

Table 3. Scale Units for Metric Flasks

\begin{tabular}{c|c|c}
\hline Size & $\begin{array}{c}\text { Graduation on Each } \\
\text { Side of Nominal }\end{array}$ & $\begin{array}{c}\text { Minimum } \\
\text { Graduations }\end{array}$ \\
\cline { 2 - 3 } $100 \mathrm{ml}$ & $2 \mathrm{ml}$ & $0.25 \mathrm{ml}$ \\
250 & 4 & .25 \\
500 & 8 & .5 \\
1000 & 15 & 1.0 \\
2000 & 25 & 1.0 \\
\hline
\end{tabular}

\section{Temperature}

4.1. The calibration temperature shall be 20 ${ }^{\circ} \mathrm{C}$. 

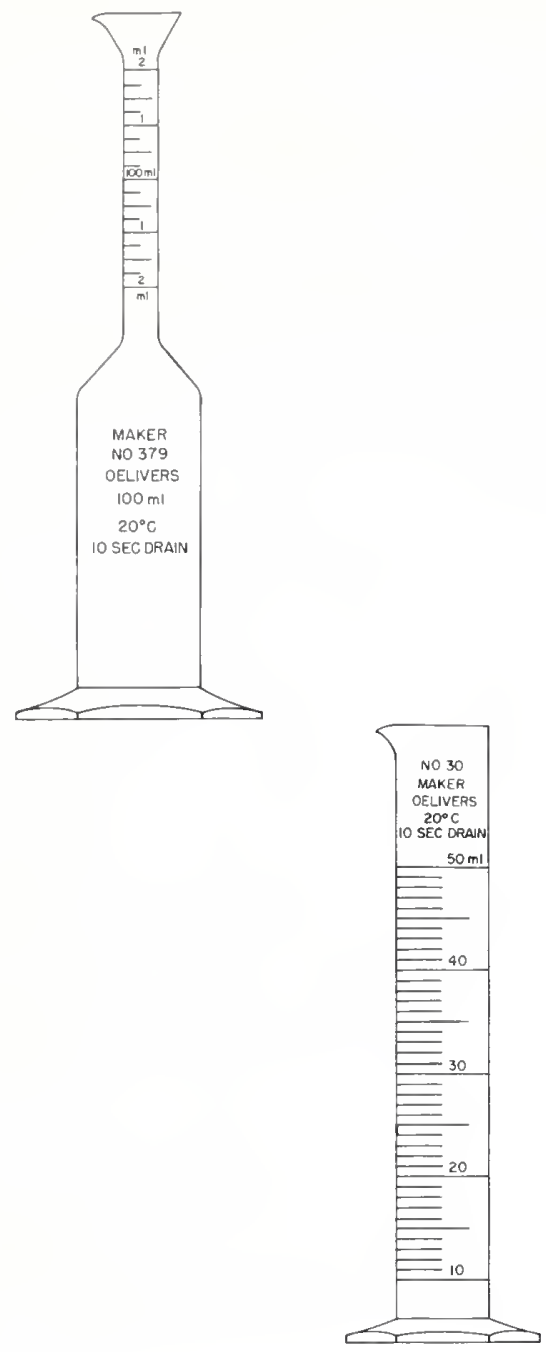

Figure 3. 100 milliliter measuring flask.

FIGURE 4. 50 milliliter cylindrical graduate.

\section{Tolerances}

5.1. The difference between the actual volume and the indicated volume at the prescribed temperature $\left(20^{\circ} \mathrm{C}\right)$ shall not be greater than that shown in table 4.

Table 4. Tolerances for Metric Field Standard Flasks and Cylinder

\begin{tabular}{c|c|c}
\hline Capacity & $\begin{array}{c}\text { Tolerance at Nominal } \\
\text { Capacity } \\
\text { Graduation }\end{array}$ & $\begin{array}{c}\text { Tolerance at Total } \\
\text { or Partial Capacity } \\
\text { (Graduated Portion) }\end{array}$ \\
\hline $100 \mathrm{ml}$ & $0.2 \mathrm{ml}$ & $0.08 \mathrm{ml}$ \\
250 & .3 & .1 \\
500 & .5 & .2 \\
1000 & .8 & .3 \\
2000 & 1.0 & .3 \\
$50 \mathrm{ml}$ & .3 & .3 \\
cylinder & & \\
\hline
\end{tabular}

\section{Definitions}

1. Main graduation lines: Lines which extend at least $3 / 4$ the circumference and are numbered.

2. Nominal graduation line: Line indicatilng the nominal capacity such as 1 pint, 1 quart, etc.

3. Subdivision lines: Lines which are between the main graduation lines and are not numbered.

4. Borosilicate Glass: Glass of a low coefficient of expansion used for most precision laboratory glassware and known by such trade names as Kimax (KG-33) or Pyrex.

\section{Abbreviations}

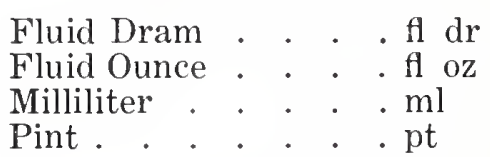


Latest developments in the subject area of this publication, as well as in other areas where the National Bureau of Standards is active, are reported in the NBS Technical News Bulletin. See following page. 


\section{HOW TO KEEP ABREAST OF NBS ACTIVITIES}

Your purchase of this publication indicates an interest in the research, development, technology, or service activities of the National Bureau of Standards.

The best source of current awareness in your specific area, as well as in other NBS programs of possible interest, is the TECHNICAL NEWS BULLETIN, a monthly magazine designed for engineers, chemists, physicists, research and product development managers, librarians, and company executives.

If you do not now receive the TECHNICAL NEWS BULLETIN and would like to subscribe, and/or to review some recent issues, please fill out and return the form below.

Mail to: Office of Technical Information and Publications National Bureau of Standards

Washington, D. C. 20234

Name

Affiliation

Address

City State Zip

Please send complimentary past issues of the Technical News Bulletin.

Please enter my 1-yr subscription. Enclosed is my check or money order for $\$ 3.00$ (additional $\$ 1.00$ for foreign mailing). check is made payable to: SUPERINTENDENT OF DOCUMENTS. Handb. 105-2 
a

(1)

0 
○

-

- 


\section{PERIODICALS}

JOURNAL OF RESEARCH reports National Bureau of Standards research and development in physics, mathematics, chemistry, and engineering. Comprehensive scientific papers give complete details of the work, including laboratory data, experimental procedures, and theoretical and mathematical analyses. Illustrated with photographs, drawings, and charts.

Published in three sections, available separately:

\section{Physics and Chemistry}

Papers of interest primarily to scientists working in these fields. This section covers a broad range of physical and chemical research, with major emphasis on standards of physical measurement, fundamental constants, and properties of matter. Issued six times a year. Annual subscription: Domestic, $\$ 9.50$; foreign, $\$ 11.75^{*}$.

\section{Mathematical Sciences}

Studies and compilations designed mainly for the mathematician and theoretical physicist. Topics in mathematical statistics, theory of experiment design, numerical analysis, theoretical physics and chemistry, logical design and programming of computers and computer systems. Short numerical tables. Issued quarterly. Annual subscription: Domestic, $\$ 5.00$; foreign, $\$ 6.25 *$.

\section{Engineering and Instrumentation}

Reporting results of interest chiefly to the engineer and the applied scientist. This section includes many of the new developments in instrumentation resulting from the Bureau's work in physical measurement, data processing, and development of test methods. It will also cover some of the work in acoustics, applied mechanics, building research, and cryogenic engineering. Issued quarterly. Annual subscription: Domestic, $\$ 5.00$; foreign, $\$ 6.25 *$.

\section{TECHNICAL NEWS BULLETIN}

The best single source of information concerning the Bureau's research, developmental, cooperative and publication activities, this monthly publication is designed for the industry-oriented individual whose daily work involves intimate contact with science and technology-for engineers, chemists, physicists, research managers, product-development managers, and company executives. Annual subscription: Domestic, $\$ 3.00$; foreign, $\$ 4.00 *$.

* Difference in price is due to extra cost of foreign mailing.

Order NBS publications from:

\section{NONPERIODICALS}

Applied Mathematics Series. Mathematical tables, maṇuals, and studies.

Building Science Series. Research results, test methods, and performance criteria of building materials, components, systems, and structures.

Handbooks. Recommended codes of engineering and industrial practice (including safety codes) developed in cooperation with interested industries, professional organizations, and regulatory bodies.

Special Publications. Proceedings of NBS conferences, bibliographies, annual reports, wall charts, pamphlets, etc.

Monographs. Major contributions to the technical literature on various subjects related to the Bureau's scientific and technical activities.

National Standard Reference Data Series. NSRDS provides quantitative data on the physical and chemical properties of materials, compiled from the world's literature and critically evaluated.

Product Standards. Provide requirements for sizes, types, quality and methods for testing various industrial products. These standards are developed cooperatively with interested Government and industry groups and provide the basis for common understanding of product characteristics for both buyers and sellers. Their use is voluntary.

Technical Notes. This series consists of communications and reports (covering both other agency and NBS-sponsored work) of limited or transitory interest.

Federal Information Processing Standards Publications. This series is the official publication within the Federal Government for information on standards adopted and promulgated under the Public Law 89-306, and Bureau of the Budget Circular A-86 entitled, Standardization of Data Elements and Codes in Data Systems. 
